\title{
„Kulturálisan vagyunk magyarok, mentalitásban szerbek vagyunk szerintem, igen." Magyarországon élő vajdasági magyar migránsok és a jugóbuli
}

\section{"We are culturally Hungarians, but our mentality is Serbian." Vojvodinian migrants in Hungary and "Yugo partying"}

\author{
VÁRADI MONIKA MÁRIA, ERŐSS ÁGNES
}

KULCSSZAVAK: migráció, zene, identitás, nosztalgia, jugónosztalgia, vajdasági identitás

\begin{abstract}
ABSZTRAKT: Tanulmányunk a vajdasági magyar migránsok egyik rendezvényével, az ún. jugóbulival foglalkozik, a szervezők és résztvevők elbeszéléseinek elemzése alapján a migráció, zene és identitás nemzetközi szakirodalomban is feltárt összefüggéseire mutatunk rá. A kibocsátó országhoz kapcsolódó zene csökkentheti a migrációval járó veszteségeket, felidézheti a migránsok maguk mögött hagyott ifjúságát, világát, egyben identitást is teremthet. A jugóbulik felidézik a volt Jugoszlávia zenei és kulturális világát, ezért írásunkban szintén választ keresünk arra, hogy e rendezvény, valamint a köré szerveződő elbeszélések vajon értelmezhetőek-e az ún. jugónosztalgia mint politikai, kulturális jelenség keretein belül. A bulit vajdasági magyarok szervezik, az eredeti szándékok szerint azért, hogy a vajdasági magyar migránsok számára találkozási és szórakozási lehetőséget nyújtsanak. A zene és a táncok, a hangulat, az ízek egyszersmind a Balkán kulturális világát idézik fel. A jugóbuli a vajdasági magyarok legalábbis egy csoportja számára olyan teret hoz létre, amelyben identitásuk „déli” vagy balkáni oldalát megélhetik, megjeleníthetik, s ez egyben arra is alkalmat ad, hogy önmagukat a magyarországi magyaroktól megkülönböztessék. A jugóbuli így a szimbolikus határmegvonás tereként is értelmezhető.
\end{abstract}

\section{KEYWORDS: migration, music, identity, nostalgia, Yugonostalgia, Vojvodinian identity}

ABSTRACT: During our fieldwork we found that a great number of ethnic Hungarians who resettled from Vojvodina go to so-called Balkan or Yugo parties in Budapest. This led to questions about what these public occasions mean for the Vojvodinian Hungarians and how they connect to the memory and commemoration of Yugoslavia. Based on this interest, the research has been enlarged: direct questions regarding the Yugo parties were incorporated into the interviews and participatory observation data about five Yugo parties contribute to deeper insight.

Yugo parties have been organised in Budapest five times a year since 2002. The primary goal of Yugo parties was to serve as a place and occasion for Vojvodinian Hungarian migrants to meet, to be together, to party. The Yugo party is a "Southern" festivity. "Southern" is understood here as pulsating rhythm, the kolo (circle dance), abandon partying till morning, the foods and

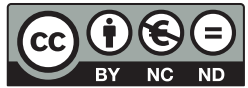


the special quality of a feeling of togetherness. The welcoming community atmosphere contributes to the fact that today Yugo parties attract a wider circle of participants, not only the prime target group, i.e. the Hungarians from Vojvodina. Now youngsters who were born in the nineties and came to Hungary to attend high school or university and do not have personal memories of Yugoslavia also go to these parties; in addition, people who travel to Budapest especially for such events from the ex-Yugoslav area; foreigners from different countries, and Hungarians from Hungary.

During the interviews, the notion of "nostalgia" often emerged. With the disintegration of Yugoslavia, the strengthening nationalism in the successor states has attempted to sharply distance themselves from the other former constituent six socialist republics of Yugoslavia by emphasizing their ethnic, linguistic, religious and economic differences. At the same time Yugoslavia was described as a failed and artificial state which only tried to supress the birth of independent successor states. Nevertheless in the 1990s, a "Yugonostalgia" emerged. Most research projects primarily study and analyse the content, subject and phenomena of Yugonostalgia in the successor states. According to some researchers, restorative Yugonostalgia has to be distinguished from reflexive Yugonostalgia. Restorative nostalgia can be characterised as the longing for fantasies of an idealised Yugoslav past. In contrast, reflexive Yugonostalgia should rather be interpreted in a political context and can be seen as a reaction to both the destructive forces of nationalist nostalgia and Yugonostalgia as a pejorative marker in the contemporary discourse about former Yugoslavia. Comparing the analyses about Yugonostalgia in the successor states we can identify both some common points and some deviations. The most obvious difference is the absolute lack of a political context or political interests. The other main item of Yugonostalgia, the Tito cult is not present at all in the case of Vojvodinian migrants. The Vojvodinian Hungarians have not participated in either discourse about Yugonostalgia, or in the typical Yugonostalgic manifestations.

If nostalgia arises from the desire to sustain the continuity of memory, in case of the Vojvodinian Hungarian migrant community the Yugo party is not only the scene to remember their youth, but it also offers a possibility to live together the continuity of one's individual walk of life - in most cases broken by involuntary migration (forced by the war and its consequences). Above all, we understand the importance of Yugo parties in Budapest in recreating and strengthening a special identity, which differentiates the Vojvodinian Hungarians from the Hungarians in Hungary.

\section{Felütés}

A színpadra lépők, kezükben a mikrofonnal, még csak készülnek az éneklésre, de amint a keverőpultnál álló DJ elindítja a felvételt és felhangoznak az első taktusok, a közönség tombolni kezd. Van, aki kiabál, más sikít örömében, a nézők tapsolnak, a kezek magasba lendülnek, és a terem önfeledten énekli a dalokat a fellépőkkel. A többség kívülről fújja a számokat, nem szükséges követniük a kivetítőn megjelenő szöveget. Nem számít, ha kicsit hamisabban énekel a színpadon álló, a hangja úgyis összekeveredik a közönségével. A verseny szabályai sem tűnnek sérthetetlennek; a férfi mellé odapenderül a fellépésre váró nő és együtt énekel a „vetélytársával”; a színpad előtt táncoló, éneklő fiatalok közül néhányan felugranak a színpadra és - kört alkotva a temperamentumos előadónő körül kólót járnak. Mások a színpadon énekelnek a versenyzőkkel, akad, aki kezében söröspohárral, cigarettával kapaszkodik a társaiba és kiabál teli torokból. A színhely egy pesti szórakozóhely, az alkalom a Balkan Party, azon belül az „ex-yu” karaok- 
everseny. A jelentkezőket a parti ötletgazdája, szervezője szólítja a színpadra, magyarról szerbre, szerbről magyarra vált, az énekesek magyarul és szerbül szólnak a közönséghez, többségük Magyarországon élő vajdasági magyar - ahogy az egyszemélyes zsüri, Rúzsa Magdi is -, a dalok a hajdani Jugoszláviában népszerü slágerek. Itt csak szerbül (szerbhorvátul) lehet énekelni. A karaokeversenyt követő „yu party”-n is a volt Jugoszláviában született popzenei számokra és „,balkáni mulatós zenére" táncolnak az egybegyültek.

\section{Bevezetés: migráció, zene, identitás, emlékezet összefüggései}

Semmit sem tudtunk ezekről a partikról, amikor elkezdtünk beszélgetni Magyarországon élő vajdasági magyarokkal. Alig néhány interjú után kiderült, hogy közülük jó páran több-kevesebb rendszerességgel részt vesznek (vettek) a Balkan Partykon - amelyeket jellemzően jugóbuliként emlegetnek, így mi is ezt a kifejezést használjuk. E tudás birtokában a következő beszélgetések során már kíváncsiak voltunk arra, hogy beszélgetőpartnereink tudnak-e ezekről a partikról, részt vesznek-e rajtuk; ha igen, mit jelent számukra, ha nem, mivel indokolják távolmaradásukat. ${ }^{1}$

Miért fontos a jugóbuli megértése és elemzése? Kutatási tapasztalatok igazolják a migráció és a zene kapcsolatát, a kibocsátó ország zenéjének a migránsok életében betöltött fontos szerepét. A zene képes arra, hogy szimbolikusan összekössön egymástól távoli tereket, különböző történelmi időket, személyes életszakaszokat, hogy „elrepítsen bennünket egy másik térbe és időbe” (Valentine 1995, 481.). A zene alkalmas egyéni és kollektív emlékek felidézésére, s a zene - hallgatása, fogyasztása, előadása, alkotása és újraalkotása - révén kifejezhetjük kötődésünket egy térhez, helyhez, társadalomhoz, az emberek egy csoportjához, életünk egy szakaszához. Más szavakkal, a zene identitást fejez ki és teremt (Baily, Collyer 2006; Cohen 1995; Leonard 2005; Margolies 2009; Martiniello, Lafleur 2008).

A zene és a tánc a migráns közösségekben különféle módokon müködhet identitást kifejező és teremtő eszközként. Az Egyesült Államokban vagy NyugatEurópában élő, dél-amerikai, afrikai, ázsiai, második vagy harmadik generációs migránsok az otthonról hozott zenei hagyományokat nyugati ritmusokkal, hangzásokkal vegyítve új müfajt és egyben identitást teremtenek (ilyen a rap vagy a rai). Míg a zenei nyelv a köztes, két kultúra és hagyomány közötti léthelyzetre reflektál, a dalok szövegeiben a migráns sorsból fakadó nehézségek, küzdelmek - a megkülönböztetés, elő́téletesség, rasszizmus élményei - jelennek meg (Bailly, Collier 2006, 175.; Margolies 2009; Simonett 2007). Magyar vonatkozású példát idézve, a Buenos Aires-i magyar diaszpórában a magyar népzene és néptánc a közösségteremtés és az identitás megőrzésének fontos eszköze. ${ }^{2}$ A Buenos Aires-i magyarok identitásteremtő gyakorlatait elemezve Kovács Nóra felhívja a figyelmet azokra a migráns közösségekben folytatott ku- 
tatásokra, amelyek rámutattak a „folklorizmus jelenségére, azaz arra a folyamatra, ahogyan a népi kultúra elemei válnak az etnikai identitás kapcsolódási pontjává az adott közösség területi és társadalmi származásától függetlenül" (Kovács 2009, 145.).

A zene és tánc révén felmutatott, megalkotott identitás, a „mi” megfogalmazása egyben a „másiktól” való elhatárolódás, szimbolikus határmegvonás. Az Etiópiából Izraelbe érkező zsidó fiatalok a reggae és a rap által teremtenek afroizraeli identitást, amellyel megkülönböztetik önmagukat a fehér izraeli társadalomtól (Shabtay 2003). Az ír népzene és tánc művelése az Angliában élő ír bevándorlók leszármazottai számára eredeti kultúrájuk felidézése és megőrzése mellett egyben az angoloktól való elkülönülés, s egy saját ír-angol identitás megteremtésének eszköze (Leonard 2005).

A zene helyet és időt teremtő, egyúttal azokat felidéző természete (Cohen 1995, 444.) nyilvánvalóan megmutatkozik a jugóbulik esetében is. A jugóbuli terét a szervezők által megszabott program, a zene kizárólagosan délszláv, illetve exjugoszláv mivolta, a lejátszott dalok szerb(horvát) nyelve éppen úgy strukturálja, mint az a mód, ahogy a vendégek „,buliznak”. A jugóbuli saját tere és ideje elválaszthatatlan attól a tértől és időtől, amelyet felidéz: a volt Jugoszláviától.

A zenének a (poszt)jugoszláv identitás meg- és újrateremtésében, valamint Jugoszlávia emlékezetének megőrzésében, újraidézésében játszott szerepe nem véletlenül vált fontos, részben az ún. jugónosztalgia összefüggésében tárgyalt kutatási kérdéssé (Lindstrom 2006; Volčič 2007, 2011). A jugoszláviai idők rockés popzenéje, amelyet a balkáni népzene és a nyugati rockzene ötvözése, valamint a fennálló renddel való szembenállás jellemzett (Debeljak 1998; ${ }^{3}$ Volčič 2007), a Jugoszlávia széteséséhez vezető és a posztjugoszláv időkben az ellenállás és a nosztalgia kifejezésének eszköze lett. A kilencvenes évek elején, a ljubljanai alternatív színtéren szervezett balkánpartikon a jugoszláv rockslágerek vagy éppen partizándalok éneklésével a fiatalok az erősödő, ezt a zenét elátkozó, tiltó nacionalista rezsimekkel és ideológiákkal szembeni ellenállásukat fejezték ki (Lindstrom 2006, 241.). A posztjugoszláv transznacionális kulturális térben a korábbi underground, kalózkiadásokban terjesztett zene képviselői már büntetlenül koncertezhetnek az utódállamokban, megindult a zenei termékek nemzeti határokon átívelő, transznacionális áramlása (Baker 2006). A jugoszláv zene, a jugórock újraéledése együtt járt egyfajta jugoszláv identitás, jugoszláv vagy balkáni életérzés átélésének és megjelenítésének igényével (Volčič 2007). Tanulmányunkban arra a kérdésre is választ keresünk, hogy Jugoszlávia emléke miként jelenik meg a bulin résztvevő vajdasági magyar migránsok narratíváiban, valamint hogy a buli által megjelenített és felébresztett nosztalgia mennyiben értelmezhető a politikai jelentésekkel is átitatott, jugónosztalgiának nevezett személyes és kollektív emlékezet összefüggésében.

A zene helyet és múltat felidéző erejét tapasztalhattuk más vajdasági migráns közösségben is. A vajdasági migránsok által alapított szervezet, a Vajdasági Magyarok Demokratikus Közössége Szegedi Tagozatának báljain a résztvevők 
magyar zenére táncolnak, mulatnak, s ezekre az alkalmakra a Vajdaságból hívnak zenészt vagy autentikus lakodalmas zenét játszó zenekart. A csárdások, a magyar nóták mellett rendre felhangoznak olyan „honvágyas” vagy Trianon után született dalok, amelyek a migránsokban a maguk mögött hagyott vajdasági szülőföld emlékét idézik fel. Ezek a bálok a maguk zenei világával teret adnak a vajdasági magyar migráns közösség összetartozásának, s ettől elválaszthatatlanul a szülőföldhöz való mély - és fájdalmas - érzelmi kötődés, végső soron a vajdasági magyar identitás meg- és újraélésének, kifejezésének. ${ }^{4}$

Interjúalanyaink narratíváiból világossá válik, hogy a jugóbulik maguk is alkalmat kínálnak a vajdasági magyar identitás megélésére és kifejezésére, de annak „déli”, balkáni elemeit emelik ki és mutatják meg. A buli a vajdasági magyar migránsok - legalábbis egy csoportja - számára lehetőséget teremt arra, hogy sajátos vajdasági magyar identitást átélve és felmutatva önmagukat a magyarországi magyaroktól is megkülönböztessék.

\section{A jugóbuli}

\section{A történet és a föszereplök}

A Balkan Party, illetve a jugóbuli története 2000 után kezdődött. István, a kezdeményező, a Magyarországra telepedett vajdaságiak összehozására kibérelt egy kis pubot, ahol az első bulit tartották. „És akkor elöször jöttek egy olyan százan, százötvenen. Úgy elég jó érzés volt, és akkor ez indult...”. Azóta különböző budapesti helyszíneken évente ötször szervezik meg a bulit. Istvánhoz hamarosan csatlakozott Sándor, aki maga is közremüködik a szervezésben, emellett a bulik állandó DJ-e. A program a két föszereplő elképzeléseit tükrözi.

A Balkan Party kulturális blokkal kezdődik, amelybe egyaránt belefér a jugoszláv utódállamokban készült film vagy vajdasági magyar szerzők újonnan megjelent könyvének bemutatója. Tíz óra felé veszi kezdetét az élő zenekari koncert (vagy karaokeverseny), melynek fellépői neves, rendszerint Szerbiából, esetleg más utódállamokból érkező zenekarok. ${ }^{5} \mathrm{~A}$ hangulat éjfél után hág a tetőfokára, amikor a program szerint elindul a hajnalig tartó jugóparti, Sándor, az állandó DJ, valamint egy vagy két, rendszerint az utódállamokból hívott DJ közremüködésével. Az autentikus balkáni hangulat megidézéséhez a film, irodalom, zene mellett az ízek is elengedhetetlenek; az ételekről (csevapcsicsa, pjeszkavica, burek) népszerü belvárosi vendéglőket üzemeltető szerb vállalkozók gondoskodnak.

István az ötletgazda és fö szervezo, akinek a kezében „a szálak összefutnak”. A harmincas éveinek elején járó egyetemi oktató, mérnök és rendezvényszervező Újvidéken nevelkedett. Édesapja vegyes (magyar, szerb, német) etnikai 
hátterű, jómódú polgári családból érkező egyetemi tanár, anyja magyar falusi gazdálkodóktól származó pedagógus, aki a városi óvodahálózat innovatív vezetőjeként szerzett hírnevet. István tőle örökölte szervezőtehetségét. A család mindig és magától értetődően magyarnak vallotta magát, erős kulturális kötődéssel az anyaországhoz. A magyar identitás mellett István élettörténetében „a multikulturalitás" tapasztalata, a több kultúrában való otthonosság kiemelkedően fontos. Büszke arra, hogy kiválóan beszéli a szerb nyelvet. Világpolgárnak vallja magát, bárhol képes otthon érezni magát. Gyermekkorában is sokat utazott szüleivel Európában és az Egyesült Államokban, rokonai élnek Brazíliában, rajong Indiáért, ahol többször is megfordult. István 1998-ban jött Magyarországra; noha az Újvidéki Egyetemre is felvették, inkább Budapestre jött tanulni, fojtogatónak érezte a mind intoleránsabb, kisebbségellenes, bezárkózó légkört, amely körülvette. Szülei egy éven belül követték, azóta itt él a család. Istvánt rokoni, baráti, szakmai, üzleti szálak kötik a Vajdasághoz, üzlettársaival létrehozott és eladásáig működtetett egy magyar és szerb nyelvü közösségi oldalt. A kommunikációs technológiák kutatóként is érdeklik és nagy segítségére vannak a bulik szervezésében, több mint ezerre - DJ Sándor három-négyezres számot említ - becsüli azt a címlistát, amelyre alapozva szervezi a bulikat. ${ }^{6}$

A bulik szervezésében és lebonyolításában István állandó partnere a Szabadkáról érkezett Sándor. Tíz évvel idősebb Istvánnál, a nyolcvanas évek végén kezdte mérnöki tanulmányait Budapesten. Az egyetemi évek után vissza akart térni Jugoszláviába, de közben kitört a háború. Mivel orvos édesapja - aki akkorra már megjárta a vukovári frontot -, véletlenül átvette és aláírta fia behívóját, az éppen otthon lévő Sándor átautózott a határon, s végleg Magyarországon maradt. Itt alapított családot, szabadkai feleségével Budapesten ismerkedtek össze. Mérnöki, műszaki tudását vállalkozásában kamatoztatja: a legkülönbözőbb rendezvények technikai és - DJ-ként - zenei lebonyolításával foglalkozik. Már a nyolcvanas években volt otthon saját diszkója (12 éves kora óta DJ-zik), szakmai tapasztalatait Amerikában és Ibizán gazdagította. Sándor testvérei is Magyarországon tanultak, ám míg nővére itt alapított családot, öccse visszaköltözött szülővárosába, ott nősült meg, dolgozik, emellett aktív tagja Sándor „nemzetközi vállalkozásának". Közösen szervezik és viszik a Vajdaságban a bulikat, diszkókat, amelyeken magyar és szerb fiatalok mulatnak. Sándor a vállalkozása "nosztalgia” ágának tartott magyarországi jugóbulikra rendszeresen hív szabadkai, zágrábi stb. DJ-ket, figyelemmel kíséri a határon túli zenei életet. A bulik zenei arculatát ő formálja: a lejátszott számok zöme a volt Jugoszláviához kötődő rock- és popzene, ${ }^{7}$ de mindig hallhatóak újabb darabok is Szerbiából vagy más utódállamból.

Noha István és Sándor vállalkozók, s maga a jugóbuli is üzleti vállalkozás - amelynek bevételei a belépőjegyekből és a szponzoroktól származnak -, hangsúlyozzák, hogy a rendezvény hasznot nem termel, és egyhangúan állítják, hogy „ezek tényleg nem a pénzról szólnak”. A kezdet kezdetén megállapodtak: ,abban a pillanatban, amikor nyüg lesz valamilyen szinten ez az egész buli, ne adj' Isten azért kezdjük csinálni, mert pénz van benne, akkor abba fogjuk hagyni. Mert hátez nem erról szól." 
István az ezredforduló után más, áttelepült vajdasági magyarokat célzó rendezvényeket is elindított. A gyermekes családokat invitáló, kulináris és kulturális élvezetekkel, játékokkal, vetélkedőkkel füszerezett Délvidékiek Találkozója öt-hat év után megszűnt, az eredeti helyszínt nem tudták tovább bérelni, újabbat nem találtak. A Vajdasági Randevú a Vajdaságból érkező magyar zenekarral, vacsorá$\mathrm{val}^{8}$ az idősebb generációkat megszólító bál volt, amely kilenc év után elhalt - az érdeklődés megcsappant, az idősek egyre kisebb számban jelentek meg, a fiatalokat a "lazább dolgok jobban érdeklik". A rendezvények elnevezése nem véletlen, István szerint a földrajzi nevek egyben identitáskategóriákat jelölnek:

„Én azt mondom, hogy mi leginkább azt szeretjük, ha vajdaságiaknak hívnak bennünket, vajdasági magyarok. A Délvidékben benne van minden, benne van a horvát rész, Baranya, benne van Szlovénia, a Muraköz, mit tudom én. Az egy tág fogalom, délvidéki. Ha Délvidéket mondasz, akkor nem vagy precíz, egy vajdasági találkozón meg egy szlovéniai magyar is eljöhet, nem azt mondom, de nem nekik szól, nem az ő rendezvényük ez. [Kérdés: És a jugó?] Ott mindenki van. Ott mindenki van; ott keveredés van."

A „mi” a vajdasági magyarokat jelenti - függetlenül attól, hol élnek -, identitá suk földrajzi és etnikai dimenziói szétválaszthatatlanok. Vajdasági találkozón - a „találkozó” fogalma migránsok számára szervezett rendezvényre utal - ugyan a tágabb Délvidékről érkező magyarok is részt vehetnek, de az nem nekik szól, mondja István, kimondatlanul is a vajdasági magyarok sajátos kollektív tapasztalataira, élményeire, kötődéseire, identitására utalva. A Jugoszlávia földrajzi és történelmi fogalmához kötődő jelzőt viselő rendezvény az, amelyen bárki részt vehet, származzon bárhonnan, ide nem csak magyarok járnak. Abban, hogy a jugóbuli a legvegyesebb közönséget tudja megszólítani és vonzani, alapvető szerepet játszik a zene, amelyhez a szórakozás sajátos minősége kapcsolódik.

A zene „déli zene”, s ha a buli hangulatát akarják visszaadni, István „ơrületról”, reggel ötig tartó „őriöngésról” beszél, sándor pedig - felidézve az első karaokepartit - úgy fogalmaz, hogy ,fejre állt a buli" és „elszabadult a pokol". A fordulatok, metaforák féktelen, önfeledt mulatást idéznek - erre az önfeledtségre utal a meghívók szövegében rendre visszatéro „asztalon táncolás/táncolni” fordulata is. A jugóbuli vonzerejéről beszélve István a közösségteremtő erőt hangsúlyozza. Gyermek- és ifjúkorának színterével, Újvidékkel állítja szembe Budapestet: míg a vajdasági városban az emberek megálltak, beszélgettek egymással az utcán, addig ez a közösségi élet ismeretlen Budapesten, a jugóbuliknak színhelyet adó nagyvárosban.

„Lehet, hogy sok embernek ez [a jugóbuli] egy identitást jelentett. Én inkább azt mondom, hogy közösséget jelent nekik. Hogy eljönnek oda, mert ugye elmehetsz bármilyen szórakozóhelyre; Budapest az egy dzsungel. Tehát rálépnek a lábadra, föllöknek, leöntenek, leütnek, kiveszik a pénztárcád. Nem olyan egyszerü ismerkedni. Lehet ismerkedni, de nem tudod, ki az, hogyan. Itt meg rögtön be tudod tájolni az illetőt. Azért ez egy közösség, és akkor lejössz, biztonságban vagy ott, sok ismerős lesz. Egy közösség, ez más érzés. Ezért szeretik. Egy közösségi érzés van. Van, hogy ötszáz ember együtt énekel, ilyet még 
nem láttam soha. Vagy együtt táncol, vagy együtt összekapaszkodva énekel.

Szóval ilyet nem nagyon lehet látni. Én nem láttam még ilyet."9

Budapest, a budapesti szórakozás tereinek metaforája a dzsungel, amelyhez - egyre erőteljesebb, a véletlen ütközésektől a tudatos erőszakosságig ívelő, durvaságot kifejező igék alkalmazásával - a kényelmetlenség, a zsúfoltság, tülekedés, a veszély képei és érzetei kapcsolódnak. Ezzel szemben a jugóbuli a biztonság szigete. Aki ide betér, számíthat arra, hogy ismerősökkel találkozik, de személyes kapcsolatok nélkül is tudható, kik járnak ide. István az ismétlésekkel (közösség), az egyediséget kifejező fordulattal (ilyet nem láttam/látni) nyomatékosítja, hogy a jugóbuli közönsége nem szórakozni vágyó ismeretlenek véletlenül összeverődő halmaza, hanem az összetartozás és a szórakozás egyedülálló élménye által összekovácsolt közösség.

\section{A közönségról}

A közönség legfontosabb csoportját, eredeti magját a kilencvenes években a balkáni háborúk, a NATO-bombázás idején Magyarországra települt vajdasági magyarok alkotják; közülük származnak a szervezők, számukra született a rendezvény. Különböző generációk tartoznak e csoporthoz, az idősebbek Jugoszláviában nőttek fel, kezdték felnőtt életüket. A keletnémet múltat felidéző ún. Ost-diszkók ${ }^{10}$ egyik résztvevőjét idézi Daphne Berdahl: „Nem csak a zene, hanem a közös emlékek. Ha szól a zene, az emberek egymásra néznek, és máris tudják, anélkül, hogy bármit is mondanának" (Berdahl 2010, 56.). Ugyanerről a szavak nélkül is újraélhető közös tapasztalatról, emlékezetről vallanak DJ Sándor szavai is:

„(...) harminc évesekig bezárólag van egy olyan, amit én észreveszek a bulikban, amikor föl lehet lángoltatni a zenével a nosztalgiát. Tehát ők voltak azok, akik még éltek is Jugoszláviában (...), a mi generációnk, hát még középiskolában is, meg mindenhol ezekre a számokra buliztunk. (...) és akkor, mikor elinditok valami számot, és kettőt szólok hozzájuk, akkor mindenki poharat a földhöz vágja, kezet fel, és elindul a nosztalgia. Ez olyan jó érzés, és ez összekovácsol mindenkit."

Sándor egyre ritkábban lát a buliban ismerős arcokat, a korosztályához tartozók családot alapítottak, munkájuk, elfoglaltságaik okán ritkábban vagy egyáltalán nem járnak el a partikra.

A fiatalabb migráns generáció tagjai a nyolcvanas években születtek, gyerek- és kamaszkorukat a poszt-titói, majd a háborúban széteső Jugoszláviában töltötték, tanulni jöttek Magyarországra a kilencvenes évek végén. Közéjük tartozik a kettős kötődésű és identitású Noémi. Édesanyja vajdasági magyar, édesapja boszniai szerb. Noha Noémi és öccse a falun élő anyai nagyszülőkkel és édesanyjukkal magyarul beszéltek, édesapjukkal szerbül, a család közös nyelve a szerb volt. „...én még ebbe nőttem bele, hogy mindenki jugoszláv (...). Multikulturális környezet, ami meghatározott minket." Noémi anyanyelve a szerb, szerb iskolába 
járt, legjobb barátai máig szerbek. „Konyhanyelven” beszélt magyarul, amikor édesanyjával eldöntötték, jelentkezik a budapesti Nemzetközi Előkészítő Intézetbe, hogy majd Magyarországon végezze felsőfokú tanulmányait. Három hónap alatt annyira megtanult olvasni, írni, hogy bejutott az előkészítőbe. Noémi azóta megszerezte diplomáját, a kollégiumban ismerte meg kárpátaljai magyar férjét, akivel Budapesten alapítottak családot. Kisfiukkal Noémi, ha kettesben vannak otthon, szerbül beszél. Magyarul pedig annyira megtanult, hogy legutóbbi munkahelyén már őt kérték meg, hogy magyarországi kollégái szövegeit átfésülje. Magyarországi meggyökeresedése, harmonikus családi élete mellett Noémit erős honvágy gyötri: hiányzik neki az édesanyja, hiányolja a legjobb barátait, az otthonát. Kisfia születéséig rendszeresen eljárt a jugóbulikra, mert ott olyan zenére táncolhatott, amelyre tinikorában bulizott. „Néha rám jön, de én azzal elintézem a honvágyat, hogy itt [a lakásban] koncertet csinálok." Noémi ilyenkor „jugoszláv zenét" hallgat.

A bulikban olyan vajdasági fiatalok is megfordulnak, akik tanulni jöttek Magyarországra, a '90-es években születtek, nincsenek saját élményeik, emlékeik Jugoszláviáról. A jugó slágereket viszont ismerik, szüleik ezeket hallgatták. őket nem a fiatalságukra, az otthonukra való emlékezés vonzza a buliba, hanem a hangulat és a közösség, a sokszínű és mégis otthonos közeg. Zoé húszas éveiben járó, Szabadkáról származó diáklány, egy vidéki egyetemen készül gyógyszerésznek. Kisgyerek volt a háborúk idején, édesapja megjárta a frontot, nem beszélt arról, amit átélt, Zoé annyit tud, hogy nem fogott fegyvert senkire. Magyar anyanyelvü és identitású családban, de vegyes etnikai környezetben nőtt fel; édesapja minden iskoláját szerb nyelven végezte, szülei munkahelyükön szerbül kommunikáltak, ő maga is barátkozott szerb gyerekekkel. A szerb nyelv ismeretének hiánya nem lenne akadály a boldogulásban, de Zoé már nem akar visszatérni a Vajdaságba, magyarországi barátjával Magyarországon vagy valahol külföldön tervezi a jövőjét. Amíg Budapesten a Nemzetközi Előkészítő Intézetben tanult, többször is járt jugóbuliban, s lelkesen idézi fel a hangulatot, a közösségi élményt.

„Jaj, hát az olyan jó! Itt Budapest kellős közepén ott egy hely, és Bijelo Dugmét hallgatunk. Az jó, én nagyon szerettem. (...) tavalyelőtt nyáron elmentem, akkor az A38-as hajón volt, az volt a legjobb buli az életemben (...) jó hangulatban telnek ezek a bulik. Meg azért is jó a hangulat, mert van az az érzésed, hogy valami összetart minket. És ez így jó."

Nem kevesen vannak, akik a volt Jugoszlávia utódállamaiból ruccannak el Budapestre egy-egy jugóbuli kedvéért, s nem csupán vajdasági magyarok. DJ Sándor egy alkalommal kívánságműsort rendezett: aki távolról érkezett, kérhetett egy-egy számot; kiderült, hogy zágrábi, ljubljanai, szarajevói vendégek is vannak a közönség soraiban. Mellettük Nyugat-Európában élő exjugoszlávok is jönnek - István kiterjedt kapcsolat- és levelezőrendszere igazi transznacionális hálózatként működik.

A bulin szép számmal vesznek részt magyarországi magyarok, érdeklődők, szórakozni vágyók, a balkáni zene és hangulat iránt vonzódók, vagy (néha tanáraikkal) a budapesti szerb és horvát gimnázium tanulói. Utóbbiak magyarországi 
kisebbségi közösségek tagjaiként kötődnek a délszláv kultúrához, míg előbbiek gyakran egy ismerős meghívására jönnek el, aztán megtetszik nekik a hangulat és rendszeres résztvevőkké válnak.

Beszélgetőpartnereink némi értetlenséggel beszélnek a külföldiekről: a karaokeversenyben résztvevő román, bolgár fiúról, francia, holland, venezuelai, indonéz, néger (sic!) vendégről.

„Ott volt egy holland srác, minek jött el, senki nem tudja, de olyan jól érezte magát! (...) voltak ott venezuelaiak is, és tök jó volt nekik, mert ezeknek a szerb zenéknek jó a dallama, meg a ritmusa, meg dinamikusak. Nem baj, ha nem érted a szöveget!" (Zoé)

Vannak azonban, akiket aggodalommal tölt el, hogy az „idegenek” lassan többen lesznek, mint a vajdaságiak.

„.... Merlinben például, ott a tavalyi is olyan volt... nagyon sok nem vajdasági volt ott, ami szerintem egy bizonyos pontig oké, meg tök jó, egy bizonyos pont után meg már így... Szóval így nem vajdasági buli volt, hanem nem tudom... Németekkel meg angolokkal volt tele a hely, amivel mondom, semmi gond nincs, azon túl, hogy onnantól kezdve ennek már nincs ilyen balkáni hangulata teljesen. (Edit)

A „nyugat-balkáni kreatív munkaero”” Budapestre irányuló migrációját elemző, 2006-ban született szakdolgozat szerzője - maga is Vajdaságból áttelepült szociológus - a budapesti „ex-yu társaságot” egyfajta szabadidő-közösségnek tekinti, amelynek közös terei a délszláv kocsmák és a jugóbulik. Azoknak a migránsoknak, akik magukban érkeznek a fővárosba és nem rendelkeznek ismerősökkel, barátokkal, a bulik jó alkalmat kínálnak a kapcsolatépítésre, barátkozásra. A szerző értelmezése szerint ebben az ex-yu közösségben „működik az elképzelt és ma már mitikus azonos helyről származás tudata, és ennek kapcsán létezik a hálózatban az egyének egymás közötti segítségnyújtása és szolidaritása". Az áttelepüléssel kapcsolatos hivatalos teendők bonyolításához szükséges információk cseréjénél többre azonban a közösségi hálózat működése nem terjed ki. A társaságot vagy közösséget, egy szűk magot leszámítva, a mozgás jellemzi. Könnyen megtalálják az újonnan Budapestre érkezők, ám sokan hamar el is hagyják, éppen az ide járó közönség miatt; azok, akik itt találkoznak és együtt szórakoznak, odahaza, a Vajdaságban nem feltétlenül keresnék egymás társaságát. A szerző e bulik jellemző vonásaként a közönség sajátos összetételét (áttelepültek, diákok, vendégmunkások, katonaszökevények mindenféle volt jugoszláv országból; mindenki beszél „,szerbhorvátul”) és az exjugoszláv nosztalgiát említi ${ }^{11}$ (Szabó 2006).

\section{A nosztalgia arcai}

Nemcsak DJ Sándor használta a jugóbulikról beszélve a „nosztalgia”, „nosztalgiázni” fogalmát, hanem néhány résztvevő is: „az ember nekiáll egy kicsit nosztalgiázni”; ,vannak ezek a jugóbulik, úgy hívjuk őket, nosztalgiával, mint volt Jugoszlávia”. 
A nosztalgia kivirágzása a posztkommunista országokban szorosan összefügg a múlt radikális diszkontinuitásával, olyan országok, mint a Német Demokratikus Köztársaság, Szovjetunió, Jugoszlávia dezintegrációjával, eltűnésével. Az átalakulással járt az a felismerés, hogy a múlt nem állítható vissza, ahogy a múltbeli diskurzusok is érvényüket veszítették (Todorova 2010; Volčič 2011). Jugoszlávia felbomlásával a „testvériség, egység” eszméjét felváltotta az utódállamok erősödő nacionalizmusa, amely az etnikai, nyelvi, vallási, kulturális, civilizációs, gazdasági különbségek hangsúlyozásával igyekezett minél élesebben elhatárolódni a többi volt tagköztársaságtól és a közös múlttól. A nemzeti, nacionalista diskurzusokban Jugoszlávia életképtelen és mesterséges államalakulatként jelent meg, amely csak gátolta e nemzetállamok önállóvá válását (Bakić-Hayden, Hayden 1992). A jugoszláv múlt emlékezetét nem csupán felülírta, hanem érvénytelenítette a nemzeti történelmek és sérelmek nemzetállam-építés szolgálatába állított emlékezete.

A posztszocialista nosztalgia gyakran idézett kutatója, Svetlana Boym különbséget tesz resztoratív és reflexív nosztalgia között. Az ún. resztoratív nosztalgia vallási és nacionalista ideológiák alapja lehet; az elveszett, vagy soha nem is létezett otthon, aranykor helyreállítását célozza, és önmagát a hagyománnyal, az igazsággal azonosítja. A reflexív nosztalgia (és nosztalgiázó) viszont nem óhajt feltétlenül visszatérni valahová, a hangsúly magán a vágyódáson van, és mivel tudatában van e vágyódás ambivalens természetének, gyakran távolságtartó, ironikus. A reflexív nosztalgikus emlékezet nem rendeződik ideológiává, közös nagy narratívává, inkább a töredezettség jellemzi (Boym 2001, lásd még Lindstrom 2006; Volčič 2007).

A resztoratív jugónosztalgia, a jugoszláv történelmi múlt iránti vágyakozás legmarkánsabb kifejeződési formája a néhai Tito marsall személyéhez kötődő kultusz (lásd részletesen Lindstrom 2006; Volčič 2011) szerte az utódállamokban. ${ }^{12} \mathrm{~A}$ reflexív jugónosztalgia a nacionalista nosztalgiák, a jugoszláv emlékezet és diskurzus politikai megbélyegzése ellenében keletkezett, de a jugoszláv múlthoz kritikával, ironikusan viszonyul, annak tudatában, hogy a személyes emlékek mindig változékonyak, töredezettek és következetlenek. A reflexív jugónosztalgia gyakran említett példája a Jugoszláv Mitológia Lexikona, a jugoszláv kultúra és mindennapok tárgyainak, termékeinek gyüjteménye. A lexikon tizenöt évig készült, szócikkeinek bárki a szerzője lehetett. ${ }^{13}$ A lexikon egyik kezdeményezője, a Nyugat-Európába emigrált horvát írónő, Dubravka Ugrešić amellett érvel, hogy a jugónosztalgia alapvető eszköz a volt Jugoszlávia mint állam és mint eszme történetének, kulturális emlékezetének megőrzésében (Volčič 2011, 194.). Ugrešić értelmezésében a jugónosztalgia a nacionalista diskurzusok, a háborúk terméke, a megbélyegzőnek szánt fogalmat ugyanis a nacionalista politika ragasztotta mindazokra, akik nem fogadták el az emlékezet „konfiskálásának”, „a felejtés terrorjának” politikáját. A jugónosztalgia a háborúk és a mindent legyőzni látszó nacionalizmusok idejéből származik, végső soron abból a vágyból fakad, hogy az egyéni és kollektív emlékezet kontinuitását megőrizze (Ugrešić 1996, idézi Volčič 2007, 2011). 
Volčič a jugoszláv kommunizmus egyoldalú nacionalista kritikájára adott ugyancsak egyoldalú válaszként értelmezi a jugónosztalgiát, amely az egymást követő háborúk, a szenvedés, a száműzetés, az utódállamokban a háborúkat követő évek nehézségei fényében idealizálja és megszépíti a jugoszláv időkben élők tapasztalatait (Volčič 2011, 194.). ${ }^{14}$ A jugónosztalgia paradoxonára is felhívja figyelmünket: mint amikor mélyen gyászoljuk azt, akit magunk öltünk meg. A Jugoszlávia iránti nosztalgia a működtetésében és fenntartásában érdekelt szereplők számára kibúvót kínál a háborúk és következményeik iránti felelősség alól, lehetetlenné teszi a szocialista múlttal és annak a háborúk kitörésében játszott szerepével való őszinte számvetést (Volčič 2007, 34-35.)

A budapesti jugóbulikban, illetve a jugóbulikhoz kapcsolódó narratívákban nem jelenik meg közvetlen politikai tartalom, a vajdasági magyar migránsok nem osztoznak a Tito marsall iránti nosztalgiában, sem az utódállamokban a jugónosztalgiát övező politikai diskurzusokban. A jugoszláv idők emlékezete a vajdasági magyar migránsok narratíváiban egyúttal hasonlít ahhoz, amelyet az utódállamokban élő egykori honfitársaikkal kapcsolatban más kutatók felidéznek, s amely a szocialista országokkal összehasonlítva kimagasló jólétről, utazási és fogyasztási szabadságról, ${ }^{15}$ az ország változatos természeti szépségeiről, kulturális és - a férfiak számára a katonai szolgálat alatt megtapasztalható - etnikai sokszínűségéről szólnak (lásd erről Burić 2010; Debeljak 1998; Petrović 2010).

A budapesti jugóbuli úgy idézi fel a jugoszláv múlthoz kötődő emlékeket, hogy zárójelbe teszi az ország széthullásához vezető háborúkat, nacionalizmusokat, az utódállamok etnikai szerkezetének átalakulását. A buli mintegy újrateremti a jugoszláv idők etnikai sokszínűségét és egységét. István szavaival:

„Nem akartuk korlátozni, mert annyi érdeklödo” volt mindenhonnan, jöttek macedónok, hogy ők is jöhetnek? Akkor jött egy horvát, hogy ők is jöhetnek-e? Most mondjam azt, hogy nem jöhettek? Szóval az úgy nem korrekt, ezért lett ez így kitalálva, hogy összefogja így az embereket, mindenki benne van."

A bulik etnikai, nemzetpolitikai szempontból idegen, semleges terepen zajlanak, ahol feloldódnak az esetleges (etnikai, nacionalista hevületből fakadó) feszültségek, itt nem esnek egymásnak a különböző nációk fiai. A „békés együttélés” DJ Sándor szerint a zenék és az előadók kiválasztásának gyakorlatában is kifejeződik:

„És ez, amit nem értek, hogy itt vagyunk Budapesten, ahhoz képest a nagy semmiben, mert bárhol Szerbiában vagy Vajdaságban meg tudnánk ezt a bulit csinálni. És mindenki Vajdaságból, Horvátországból, Szlovéniából jön ide, és itt bulizik; nem pedig ott. (...) itt jobban el tudják magukat ereszteni, mert neutrális a hely, nem félnek attól, ami esetleg incidensek érték, hogy nemzetiségi problémák lesznek (...) Én nem szoktam abszolút ezzel foglalkozni, hogy most milyen zenét engedünk, hogy most ez horvát, bosnyák, szerb vagy hova tartozó az együttes, vagy az alkotó, vagy bárki. A jó zene és a jó szöveg, ez a lényeg. És soha nem volt még hál' istennek incidensünk ilyen nemzetiségi problémákból. Mindenki nagyon együtt van, nagyon bulizik." 
A szervezők szavai alapján úgy tünik, mintha itt Budapesten megvalósulna az a remény, hogy a populáris kultúra, s annak részeként a zene segítene az utódállamok, az utódállamokban élő emberek közötti viszonyok normalizálásában, a megbékélés diskurzusának kibontakozásában (Pauker 2006). A rendezvény hangsúlyozott apolitikusságán azonban a legnagyobb körültekintés, a kizárólag a minőségre figyelő zenei válogatás ellenére is rést üt a közelmúlt. A turbofolk ${ }^{16}$ utódállamok-szerte rendkívüli népszerüségnek örvendő, a közvéleményt viszont megosztó sztárja Ceca Ražnatović, a merényletben meggyilkolt, háborús bünös szabadcsapatvezér, Arkan özvegye, akinek alakja és zenéje elválaszthatatlan Milošević nacionalista, háborús rezsimjétől (Baker 2007). DJ Sándor maga sem kedveli a müfajt, ritkán kerül sor arra, hogy egy-egy Ceca-számot lejátsszon a buliban. Ebben az esetben azonban az esztétikai szempontokat felülírhatja az a traumatikus történelmi időszak, amelyhez a müfaj és az előadó felvirágzása kapcsolódik. Egyik beszélgetőpartnerünk, József azért nem jár jugóbulira, mert sokkolta az élmény, hogy az egyetlen rendezvényen, amelyen részt vett, Ceca zenéjére táncoltak a vendégek.

„...egy ilyen turbofolk undorító valami. (...) És az emberek arra mulattak. Az egy dolog, hogy az embernek a zenei ízlése milyen, meg jó, x ital után tök mindegy, meg balkáni ritmus. De hogy ez a Ceca, az Arkan özvegye, hogy erre Budapesten mulatni és magyar... ez számomra az identitás totális konfúziójának szimbóluma volt. Még ha tetszene is, szégyelleném, hogy a Cecára mulatok. Otthon [Vajdaságban] is barátaim, hogy a Ceca, az jó. Hát hallgasd! De tudod te, hogy ki az, és mit jelentett a mi...? Pont azért kellett eljönni, mert ilyen emberek és ilyen kultúra uralkodott el!"

József szavai arra a kételyre utalnak, hogy vajon az önfeledt szórakozás lehet-e ártatlan a közelmúlt feldolgozatlan traumáinak fényében, illetve lehet-e Jugoszláviára emlékezni anélkül, hogy elfelejtenénk, milyen szenvedések árán bomlott fel. Másik beszélgetőpartnerünk, Ádám a jugóbulival szemben rendkívül éles kritikát fogalmazott meg. Ádám identitásának sarokköve a magyarsága: „életem legnagyobb ténye, fontos dolog, amit érték megörizni”. Kisebbségi magyarként megmaradni egy szilárd erkölcsi világrendhez való hűséget jelent. Ádám nézőpontjából a jugóbuli lélektani pótlék azok számára, akik Magyarországon nem boldogulnak, a titói Jugoszlávia iránt táplált nosztalgia pedig kudarc, önbecsapás.

„Azt nem annyira szeretem, ha valami nincs a helyén, ez sok szempontból valamilyen tünet, hogy itt a vajdasági vagy mindenhonnan összejött magyarok, meg a mindenhonnan összejött exjugoszláv népség, ott így sír, miért nincs már Jugoszlávia. Hát miért lőttétek szét?!"

A háború, a szerb nacionalista politika kényszerítette ki a vajdasági magyarok tömeges migrációját. A Vajdasági Magyarok Demokratikus Közösségének egyik alapító tagja arról beszélt, hogy a vajdasági magyarok báljaikban „bojkottálták” a kólót. Úgy is fogalmazhatunk, hogy nem voltak hajlandóak „déli módra” táncolni, „pedig mi nem a szerb népre haragszunk, hanem Miloševićre, a szerb hatalomra". ${ }^{17}$ A háború, a kisebbségiként elszenvedett kényszerü migráció élménye számukra lehetetlenné teszi a jugoszláv múlt nosztalgikus emlékezetét. 
Interjúink alapján úgy gondoljuk, hogy ha a budapesti jugóbuliban résztvevők narratíváiban megjelenő „nosztalgia” természetét kívánjuk megérteni, akkor érdemes a fogalom legáltalánosabb, legsemlegesebb jelentéséhez fordulnunk. A 18. században felbukkant fogalom a görög nostos (hazatérés) és az algia (vágyakozás - valami után, ami nincs) összetételéből keletkezett. Egy svájci orvostanhallgató olyan gyógyítható betegségként definiálta, amelyet a szülőföldjüktől távol élők (katonák, tengerészek, városba került falusi cselédek) esetében diagnosztizált. A honvágy tehát elválaszthatatlan a nosztalgia fogalmától. És noha a honvágy egy meghatározott, elveszített hely utáni vágyódásként értelmezhető, a nosztalgia egyúttal egy más idő, az elmúlt gyermekkor, a fiatalság vagy egy más korszak utáni vágyakozást is jelent (Boym 2001, 2007). A vajdasági magyar migránsok esetében a nosztalgia forrása maga a kényszerü migráció.

\section{Migráció, zene, identitás - történetek és értelmezések}

Edit hatéves volt, amikor édesapja 1993-ban, a besorozás elől Magyarországra jött. Állást is talált, de felesége és gyermekei csak 1999-ben követték őt, amikor fennállt a veszély, hogy Edit bátyját is behívják. Abban, hogy a család hat éven át külön élt, az édesapa játszott döntő szerepet. Hétvégi látogatásaikor mindegyre hangsúlyozta, hogy nem érdemes átköltözni Magyarországra, Budapest lakhatatlan város, ő maga csak addig tervezi ittlétét, míg az otthoni helyzet végre rendeződik. Az állandó ideiglenesség a család áttelepülése óta is tart: Edit szülei nem siettették a helyzetüket legalizáló papírok beszerzését, albérletben laknak, az édesapa vágya, hogy legalább nyugdíjas éveire visszaköltözzék vajdasági otthonába, ahová - amikor csak lehet - hazajárnak. Edit egyetemi tanulmányainak végéhez közeledik, ő - apjával szemben - otthon érzi magát Budapesten, de jövőjét más országban is el tudja képzelni. Edit a jugóbulik rendszeres résztvevője; itt alkalma nyílik arra, hogy találkozzon vajdasági ismerőseivel - itt élőkkel, átruccanó otthoni barátokkal -, meg lehet tudni, kinek hogy megy a sora. A bulik zenéjét is szereti. A balkáni zene Edit életében folyamatosan jelen van, jelentése és jelentősége azonban változó. Nagyon fontos volt akkor, amikor gyerekként el kellett szakadnia az otthonától, barátaitól - ebben az időszakban a veszteségeket, a honvágyat és a magyarországi, iskolai beilleszkedés nehézségeit segített elviselhetővé tenni.

„Nálam például ezeknek a zenéknek a hallgatása abban az időszakban volt a legintenzívebb, amikor tényleg fájt nem ott lenni. (...) Tehát amíg itt utáltam az általános iskolámat, ott annál inkább kerestem a mindenféle kötelékeket. (...) Rendszeresen jártunk haza, nagyon örültünk a bátyámmal, amikor megszereztünk egy újabb szerb kazettát, vagy CD-t, vagy mit tudom én, mit hallgattunk akkor... Igen, tehát akkor volt ez nagyon erös, és azt gondolom, hogy ha most hallgatok, tehát most már nem hallgatok naponta szerb zenét. (...) Most megvan egy másik oldala, mondjuk egy Goran Bregović meg Boban 
Marković, akik meg inkább így az egyetemi időszak alatt lettek nekem érdekesek, és akkor kezdtem el óket hallgatni. Mert ugye abban azért benne volt ez a cigányság is, »Ú, de jó, mindenki ezt hallgatja az egyetemen; nekem ehhez pluszban van egy kötődésem...." Tehát ez megint más... de hogy amikor ezeket, ezeket a nagyon nyálas, ilyen balladákat, mondjuk, meghallgatom, akkor nekem az a nosztalgia, azt gondolom, az arra az időszakra..."

A migrációt kísérő veszteségek zenével is csillapított fájdalma múlttá vált, a nosztalgia ma már nem a honvágy, hanem a honvágy emléke. Edit zenei ízlésének alakulása úgy is értelmezhető, mint az azonosság/azonosulás és a különbség/elkülönülés közötti egyensúly helyreállítása. Az általa szívesen hallgatott balkáni zene budapesti egyetemista társai körében is divatos, így ízlésével, zenehallgatási szokásaival nem üt el a környezetétől. Mi több, ha nem is származása, de szülőföldje földrajzi határai és kultúrája révén meghitt viszonyban áll a balkáni cigányzenei hagyománnyal. S ez identitásának sarokköve: Magyarországon (ha nem is nagyon, de kicsit) megmaradni másnak, vajdaságinak.

Vajdasági mivolta, vegyes - magyar, horvát, német - etnikai háttere Edit számára többletet, értéket jelent, ami Magyarországon - akár csak egy társalgás során is - általában a különlegességnek szóló érdeklődést válthat ki. Edit felidéz egy olyan iskolai eseményt, amely miatt utólagos értékelése szerint feladott egy darabot vajdasági identitásából.

„Hát ugye nagyon máshogyan beszéltem még anno, és egy konkrét helyzet meg is van a fejemben, amikor, valahogy azt gondolom, hogy igy hangosabban, vagy agresszivebben, vagy valahogy biztos máshogyan beszéltünk, és akkor, mindegy, valaki után szólni akartam, és akkor az nekem normális volt akkor, hogy egy ilyen »Hööő!"«, valami ilyen hangot adtam ki, és akkor így az a valaki rám förmedt, hogy - úristen, mekkora nagy paraszt vagyok. [Nevet.] És hát akkor nyilván emiatt én nagyon szégyenkeztem, és amit meg most utólag élek meg negatívumként, hogy én ott így beadtam a derekam, hogy nem tartottam... Jó, azt gondolom, hogy így nyilván kellett azon finomitani, de azt nem szeretem, hogy közben most egy nagyon pesties beszédmódot vettem föl, és nagyon sokszor érzem én is, ahogy affektálok. És, szóval tök jó lenne, hogyha tudnék ezekkel a zártabb magánhangzókkal beszélni még mindig. Vagy hogy pont, hogy ez is megadná azt a különlegességet, azt gondolom, ami, ami mondjuk egy beszélgetés alatt akár mondjuk, elojöhet. Elmondom, hogy honnan származom, csak hát már nem beszélek szerbül, és nem is tudok úgy beszélni, mint egy igazi vajdasági magyar..."

Edit vajdasági identitása elválaszthatatlan a nyelvtől mint olyan adottságtól, amely megkülönbözteti őt a magyarországi magyaroktól, illetve amely alapján az ő identitása is felismerhető és azonosítható mások számára. Az iskolai incidensben ez az identitás leértékelődött. Osztálytársa a hanglejtése, hangereje és - ez nyilvánvaló volt az Edit elbeszélését kísérő gesztusokból - heves gesztikulálása miatt nevezte Editet „parasztnak”, ami egyaránt jelent vidékiséget és műveletlenséget. Ez a megszégyenítő élmény nemcsak arra ösztönözte őt, hogy az új kör- 
nyezetéhez való alkalmazkodás jegyében halkabban, visszafogottabban beszéljen, hanem a zártabb magánhangzókkal jellemezhető akcentusát is elhagyta, és felvette a „pesties” beszédmódot, amely mintegy a „paraszt” megfelelo ellentétpárja, az „affektálással”, mesterkéltséggel azonos. Vajdaságban élő barátai körében viszont a pesties beszédmód az otthoni, hátrahagyott közegtől való eltávolodás, élesebben az elszakadás és e közeg lenézésének biztos jele. Edit veszteségként éli meg, hogy elhagyta az akcentusát s hogy már a szerb nyelvet sem beszéli. Ezzel vajdasági identitása mások számára észrevehetetlenné (nem hallhatóvá) vált - s ezzel csökkent e vajdasági identitás különlegessége, vonzereje is.

A jugóbulikon Edit vajdaságiként mulat, ahogy magyarországiak nem tudnak: „...otthon például, mondjuk a magyar bulik is úgy zajlanak, hogy egy ideig, mit tudom én, mindenféle ilyen menö zene megy, és akkor a végén vagy nem a végén, úgy kettő óra körül mondjuk elkezdödnek ezek a szerb balladák szólni, és akkor átmegy az egész, egy ilyen nem tudom, közös összeölelkezős, ilyen félig sírós, üvöltős, mosolygós, éneklős dologba."

Robert negyvenes évei végén jár, 1991 nyarán a besorozás elől érkezett Magyarországra. Egy légitársaság alkalmazottjaként dolgozik, emellett amatőr zenész. Robertben nagyon erős a „magyar nemzeti öntudat”, Magyarországról anyaországként beszél, ahová azonban, ha nincs háború, nem jött volna, s ahol nem is érzi igazán otthon magát. Mélyen él benne a „fogadtatás” emléke, ami lerombolta a kisebbségi sorban Magyarországról szőtt illúzióit; egy rendőr kérdezte tőle: „most, hogy lőnek, féltjük a seggünket?!”. Úgy véli, hogy a magyarországi embereket az empátia hiánya jellemzi. Azért is lakik albérletben, mert egy saját lakás a végleges magyarországi letelepedés melletti döntést jelentené. Legszívesebben hazamenne, de biztos abban, hogy nem lenne munkája. Így nem is mozdul. A zenével kamaszkorában kezdett el foglalkozni, a kis falusi együttes tagjai az akkori ismert magyarországi együttesek - Omega, Edda, Piramis, LGT - számait játszották; felnéztek rájuk, azonosulni tudtak a szövegekkel. „Büszkék voltunk arra, hogy magyarok vagyunk”, s ezt a zenéjükkel is kifejezték. Húsz évvel azután, hogy elhagyta a Vajdaságot, számára a jugó, balkáni zenére mulatás egyfajta túlélési technikát jelent.

„....azért van ez a jugóbuli is, mert ezt a mókuskereket sokan nehezen viselik itt, a pesti, gyors tempót, az elidegenült világot. És ez olyan, hogy ott el tudjuk engedni magunkat. (...) itten ugye nem kell úgy viselkedni, hanem itt el lehet engedni balkáni módra az embernek magát. Lehet ugrálni, kiabálni, hangosan énekelni. Ez a déli életvitelnek a megtestesülése. És ezért volt fontos ez, hogy az ember ott jól ki tudja magát tombolni, és akkor megy az élet tovább. És akkor két-három hónapig kibírja az ember. (...) Szerintem azért szeretnek a vajdaságiak oda elmenni, mert ott nem kell viselkedni. Mert ugye itt nekünk, ha bevallják, ha nem, de azért itt valamelyest viselkedni kell. Ez a forma nagyon fontos itt Magyarországon. Részben viselkedni kell, és ott meg nem kell annyira viselkedni."

Robert a budapesti élet felgyorsult tempójával és monotóniájával szemben a jugóbulit az ellazulás, a fegyelmező szabályoktól való megszabadulás, a „tombolás” 
helyszíneként jellemzi. A jugóbuli alkalmat teremt a déli életvitel megélésére egy olyan magyarországi világban, amely Robert szerint a szabályok betartására, önkorlátozásra és bizonyos színlelésre kényszeríti a vajdaságiakat. A beszélgetés során részletesen kifejtette azt a véleményét, hogy Magyarországon az emberek - legyen szó a munkáról vagy éppen a férfiak udvarlási szokásairól - túl sokat adnak a formaságokra, felületesek, nem a tartalomra, a lényegre koncentrálnak. Robert elbeszélésében a déli/balkáni és a magyarországi/budapesti jelzők egymással összebékíthetetlen világokhoz kapcsolódnak. Míg délen (ott) az emberek az élet élvezetét előbbre tartják a kötelességeknél, addig Magyarországon (itt) nem képesek ellazulásra, az élet élvezetére. „Ez a déli, balkáni mentalitás, hogy eszünk, iszunk, szórakozunk, és majd, ha marad pénzünk, akkor kifizetjük a számlákat. Ez a balkáni mentalitás, míg itt az, hogy fizetjük a számlákat, meg idegeskedünk azon, hogy mit mond a tévé. Hát ott más a sorrend."

Beszélgetőtársaink - függetlenül attól, hogy járnak-e jugóbuliba vagy sem -, a maguk identitását a magyarországi magyarokkal összehasonlítva gyakran fogalmazzák meg oppozíciókban. A temperamentumos, laza vajdaságiakkal szemben a magyarországiakat a formáknak, viselkedési kényszereknek való megfelelés jellemzi. A vajdaságiak őszinték, szókimondóak, míg a magyarországiak kerülik a nyílt beszédet. A vajdaságiak nem sajnálják az időt egymás társaságára, a közös kávézásra, vendégszeretőek, a magyarországiak befelé fordulnak, zárkózottabbak, s míg a vajdaságiak életszeretők, a magyarországiak hajlanak a búskomorságra, szorongásra, önsajnálatra. A vajdasági és magyarországi férfiak összehasonlításakor sem utóbbiak felé billen a mérleg nyelve; előbbiekhez erő, tartás, utóbbiakhoz inkább a nyámnyilaság kapcsolódik. Mindazok a mentalitás- és karakterbeli különbségek, amelyek a migráns narratívákban megjelennek, lényegében azt a célt szolgálják, hogy azonosíthatóvá tegyék a migránsok egyszerre magyar és vajdasági identitását. István, a bulik főszervezője így jellemezte a vajdasági magyar migránsokat: „kulturálisan magyarok vagyunk, mentalitásban szerbek vagyunk”. Ez a kettős identitás, kötődés a Vajdaság multietnikus karakterében, több nemzetiség együttélésében, a vajdasági magyarok kisebbségi helyzetében, egy sajátos kollektív tapasztalatban gyökerezik.

Tamás, aki egy szerb, magyar és angol nyelven is előadó zenekar vezetője, a magyarok és délszláv népek, elsősorban a szerbek együttélését olyan adottságként értékeli, amelytől a magyarok gazdagodtak, a kétféle mentalitás találkozásából egy új minőség született: „...én úgy érzem, hogy mi, vajdaságiak úgy valahogy magunkba szivtuk azt, ami jó abból a másik mentalitásból. (...) a többségünk, az inkább innen is, meg onnan is inkább a jót, és abból gyúrtunk valamit." A több nemzetiség együtt- és egymás mellett élése kulturális kölcsönhatásokat eredményezett: „kicsit átvettünk innen is, onnan is”. Néhány beszélgetőpartnerünk, köztük Robert, a többnemzetiségű Vajdaságban kisebbségiként megélt tapasztalatról beszélve azt hangsúlyozta, hogy ebből fakad nyitottságuk és toleranciájuk más nemzetekkel, kultúrákkal, szokásokkal szemben - amelyet gyakran hiányolnak Magyarországon. A Vajdaságot magától értetődően jellemezte az 
etnikai, kulturális sokszínűség és tolerancia, ami Jugoszláviában a titói politika rangjára emelkedett.

„Akármennyire is mesterséges koholmány volt ez a Jugoszlávia, de minket ugye úgy neveltek, hogy ez egy "testvériség, egység", meg hogy ez a sok nemzetiség, ez milyen jó. És végül is nincs ezzel semmi gond, és jó is az. De tényleg nagyon sok jó embert megismertem, aki bosnyák, vagy horvát, vagy szlovén, vagy szerb. És Vajdaságban szintén. Tehát ez Vajdaságban egyébként is jellemzo", hatványozottan jellemzö volt ez a sokszínüség, ez a nemzeti sokszínüség, hogy éltünk egymás mellett, akár együtt is, magyarok, szlovákok, ruszinok, szerbek, horvátok, bunyevácok."

Robert narratívájában azért kapcsolja össze a vajdasági magyarok sajátos tapasztalatából sarjadt identitását a nosztalgia fogalmával, mert az a világ, amely e tapasztalatot és identitást lehetővé, megélhetővé tette, a délszláv háborúk és a szerb nemzetállam kialakításának politikája nyomán már nem létezik, csak emlékekben idézhető fel és élhető újra.

„Hogy mondjam, ez a nosztalgia a vajdasági mentalitás után. Mert ugye már otthon sincs meg az, ami volt régebben, tehát a mi korunkban. Ez a balkáni háborúk elötti időszak, amikor ugye relatív jól éltünk. Tehát ott is megváltoztak... Egy csomó boszniai szerbet, meg Koszovóról is betelepitettek oda, ráadásul eléggé szisztematikusan, tehát olyan helyekre, ahol magyarok voltak többségben, tehát próbálták, ugye azért nem véletlenül, megváltoztatni az arányokat. Úgyhogy azért mondom, hogy ez egyfajta olyan nosztalgia, amit már csak magunkban találunk meg, tehát ez már nem létezik sehol. Tehát ez volt, és ez megszünt, és ez nincs már. (...) Hogy mondjam, nagyon specifikus dolog, mert ugye más embernél ez úgy van, hogy nosztalgia a fiatalság után, és ennyi. De a mi fiatalságunk egybeesik egy olyan dologgal és egy olyan országgal, ami idöközben megszünt. (...) Ez egy olyan életérzés, ami úgy meghatározta a fiatalságunkat, és ugye hogyha ez nem szünik meg, akkor gondolom... Tehát időről időre haza lehet menni, és az ember feltölti magát, feltöltödik. De ez megszünt. Ezt nem lehet sehol, ezt már csak magunkban találjuk meg, hogy leülünk, és beszélgetünk, és akkor egy ilyen kis társaságban ez újraéled ez az életérzés."

A jugóbuli Robert és a volt Jugoszláviában felnőtt generációk számára olyan teret kínál, amelyben felidézhető és újraélhető egy személyes és egyben kollektív tapasztalathoz kötődő „életérzés”, amely egyszerre idézi fel az ifjúság éveit és a jugoszláv/vajdasági multikulturalitás egyediségét. A nosztalgia itt a veszteségekből s a miattuk érzett fájdalomból fakad, abból a felismerésből, hogy összetört és végérvényesen, visszahozhatatlanul eltűnt az a világ, az a tér és idő, amelyhez e sajátos és összetéveszthetetlen tapasztalatok kötődnek. 


\section{Összegzés}

A jugóbulit szervező és látogató vajdasági magyar migránsok elbeszélései alátámasztják a migráció, zene és identitás szakirodalomban feltárt összefüggéseit. Láthattuk, hogy a vajdasági magyar migránsok számára a maguk mögött hagyott ország zenéjének hallgatása, éneklése, az arra való mulatás lehet a migrációt kísérő veszteségek enyhítésének eszköze, felidézheti az elhagyott otthont és az eltűnt ifjúságot, egyúttal sajátos identitást teremthet, fejezhet ki.

A jugóbulikat vajdasági magyarok szervezik, a rendezvény eredeti célja szerint a Magyarországon élő vajdasági magyarok számára nyújt találkozási és szórakozási lehetőséget. A buli sajátossága, hogy a zene, a táncok, a dalok nyelve, akárcsak a bulihoz kapcsolódó ízek, a hajdani Jugoszláviát, illetve a Balkán kulturális terét, világát idézik fel. A jugóbuli a résztvevő vajdasági magyar migránsok legalább egy csoportja számára lehetőséget kínál arra, hogy identitásuk „déli”, „balkáni” oldalát átélhessék és felmutathassák, egyszerre kínálva az összetartozás és - kimondva vagy kimondatlanul - a magyarországi magyaroktól való elkülönülés élményét.

A jugóbuli a résztvevők egy markáns csoportja számára a múltra való emlékezésre, a nosztalgia átélésére kínál teret. A vajdasági magyar migránsok esetében az általuk a jugóbulik kapcsán (is) emlegetett nosztalgia és honvágy forrása maga a migráció. Ha a migrációt megelőző idő egybeesik az érintettek gyermekkorával és fiatalságával, a nosztalgia a maguk mögött hagyott otthon és fiatalság iránti vágyakozást (is) jelenti. A vajdasági magyar migránsok életében a migráció közvetlen vagy közvetett módon Jugoszlávia háborúk sorával kísért széteséséhez kapcsolódik. Minél idősebb valaki, minél hosszabb ideig élt Jugoszláviában, a migrációval járó veszteségek, hiányok, fájdalmak annál nagyobb eséllyel fonódnak össze a szétesés (váratlan és drámai) tapasztalatából fakadó és a vajdasági multikulturális világ eltűnéséhez kapcsolódó veszteségekkel. Ha a nosztalgia az emlékezet kontinuitása megőrzésének vágyából fakad, akkor a vajdasági magyar migráns közösség idősebb generációi számára a jugóbuli nem csupán a fiatalságra való emlékezés tere, hanem a jellemzően kényszerü (a háború és következményei miatt kikényszerített) migrációval megtört életút kontinuitásának (közös) megélésére is alkalmat ad.

\section{Jegyzetek}

1 Amellett, hogy Magyarországon élő vajdasági magyar migránsokkal készült interjúk során érintettük ezt a kérdést, interjút készítettünk a jugóbuli két szervezőjével, és három, ugyancsak Magyarországon élő vajdasági magyar zenésszel, akik egy alkalommal felléptek a partin. Az interjúk mellett a résztvevo"-megfigyelés módszerét is alkalmaztuk: 2010 ősze és 2012 nyara között öt partin vettünk részt. A tanulmányban a parti szervezői és a zenészek mellett azokat az interjúalanyainkat szólaltattuk meg, akik többé-kevésbé rendszeresen részt vettek/vesznek 
e bulikon, illetve a jugóbuliról mesélve markáns narratívákban jelenítették meg a migráció, a zene, a nosztalgikus emlékezet és az identitás összefüggéseit.

2 „Fontos megjegyezni, hogy a magyar nóta szeretete fontos szerepet tölt be az etnikai identitás fenntartásában a legkülönbözőbb hátterű argentínai magyar bevándorlók csoportjaiból származók esetében." (Kovács 2009, 147.) Kovács Nóra arról is beszámol, hogy a Buenos Aires-i magyar diaszpóra aktív közössége gyakran hív meg Magyarországról táncoktatókat, akik számukra autentikus magyar, fóként erdélyi néptáncot oktatnak. Szívesen látnak vendégül magyarországi népzenekarokat és táncegyütteseket, de ugyanígy cigányzenekart is.

3 „A jugo-rock sohasem rejtette véka alá, hogy a hegyi pásztorok énekével és makedón furulyák hangjával kacérkodik, melyeket a mi rockereink anyukái még a mezei munka alkalmával hallgattak. Természetesen a jugo-rock is a basszus, a szólógitár, a dobok és a vokál klasszikus képletéből indult ki. Ugyanakkor merített az élő népdal forrásaiból (...).” (Debeljak 1998, 23.) A VMDK Szegedi Tagozatának bálján - amelyen magunk is részt vettünk - a kifüggesztett molinón a „délvidéki magyarok” bálján köszöntötték a vendégeket. A Délvidék földrajzi fogalmának alkalmazása arra a történelmi, Trianont megelőző időszakra utal, amikor Vajdaság a Magyar Királyság része volt.

5 Az általunk meglátogatott partikon láthattuk például a Guca címủ filmet a trombitás Marko Marković főszereplésével - noha a televízió vetítette szinkronizált változatát is, szerb nyelven -, és Srđan Dragojević szerb rendezo „Szent György megöli a sárkányt” című filmjét, premier előtti vetítésen, szerb nyelven, angol felirattal. 2011 júliusában pedig drMáriás „Nem élhetek Milošević nélkül” címü könyvét mutatta be a szerző és Szombathy Bálint. A kulturális blokk után következő élőzenei programon felléptek már a gucai fúvós fesztivál nyertesei, 2011 nyári partiján egy vajdasági áttelepülők által létrehozott alkalmi zenekar és egy magyarországi horvát zenészekből verbuválódott együttes szórakoztatta a közönséget.

6 Egy másik, Vajdaságból érkezett beszélgetőpartnerünk, Balázs, aki kulturális menedzserként és intézményvezetőként a nép- és világzenei produkciók elkötelezettje, szervezője és kiadója, így jellemzi ennek a hálózatnak az erejét: „Hát most ugye ez a Facebook-kultúra, hogy az ember egyenként tudja a barátait. Ő nagyon ügyesen felépitette ezt, megelőzve a korát. Neki egy akkora adatbázisa van, ami ôt eltarthatná már élete végéig. Most, ha ő azt mondaná, hogy hajóra, akkor mindenki a hajóra menne, vagy csatába, akkor csatába. Mert az Istvánnak megvan az a tömegbázisa."

7 Ennek a korszaknak emblematikus zenekara a szarajevói Bijelo Dugme (Fehér Gomb), amelynek egyik alapító tagja a később világhírnévre szert tett Goran Bregović. Más jeles, a jugóbulikban is gyakran játszott zenekar a Riblja Corba, a Plavi Orkestar. Ezek az együttesek a balkáni népzenei motívumokat a modern rockzenével házasító egyedi stílust teremtettek (Debeljak 1998; Pauker 2006; Volčič 2011).

8 A VMDK Szegedi Tagozata által szervezett bálok is ilyen rendezvények. Hozzá kell tennünk, hogy a szegedi bálokon résztvevők is a közép- és idősebb generációhoz tartoznak, fiatalokat nemigen látni a vendégek között. István az említett bálok, találkozók, bulik mellett különböző rendezvényeket támogat, így például a vajdasági magyar egyetem javára szervezett jótékonysági bált, amelyen - az esemény kisebbségpolitikai jellegének és jelentőségének megfelelően magyar népzene szólt.

9 István mesél arról is, hogy kibontakoztak már házassággal megpecsételt kapcsolatok, születtek már jugóbuli-gyerekek is.

10 Az Ostalgia a volt Kelet-Németország iránt érzett nosztalgia kifejezésére szójátékkal alkotott fogalom. A téma talán legjelesebb kutatója Daphne Berdahl volt.

11 Az egyik interjúalany ironikus jellemzése szerint „Valószínü, hogy Budapest az egyetlen olyan város, ahol ma is rendszeresen rendeznek olyan bulikat, ahol horvát, szerb, macedón és vajdasági magyar közösen mulat egy nyolcvanas évekbeli szarajevói együttes zenéjére, és visszasírja a titói Jugoszláviát" (Szabó 2006).

12 Az albánok Koszovójában a jugoszláv múltnak, a múltra való emlékezésnek sem nyilvános, sem alternatív terei nincsenek, a nemzeti függetlenségi küzdelem narratívája a közös történelem minden nyomát eltörölte. Az erőszak, a szenvedés pedig megsebezte a jugoszláv idők személyes emlékezetét (Schwandner-Sievers 2010). 
13 Magyarul részleteket lásd Ugrešić 2005.

14 Volčič az utódállamokban a jugoszláv nosztalgia három, egymást gyakran átfedő típusát azonosította. A revizionista nosztalgia az újraegyesítés politikai programja részeként véli megvalósíthatónak a múlt ígéretét. Az esztétikai nosztalgia alapvetően kulturális jelenség, amely az autentikus jugoszláv múlt megőrzésére hív fel, míg a menekülő vagy utópikus nosztalgia a piachoz kapcsolódik, amely tetemes hasznot húz az idilliként bemutatott jugoszláv múlt utáni vágyódásból (Volčič 2007, 28.).

15 „A jugoszláv szocialista rendszer mindaddig nem volt veszélyben, amíg az emberek a nyugati bevásárló turizmushoz füződő jogaikat gyakorolhatták (...) az összeomlásban szerepet játszott a fokozódó elszegényedés is, ami hirtelen jelentős tömegeket fosztott meg attól a lehetőségtől, hogy akár a legolcsóbb hamis farmernadrágot megvegyék." (Bartlett 2000, 126.). Bartlett szerint az egykori Jugoszláviában a fogyasztás identitásteremtő s egyúttal legitimációs eszközként szolgált. Több vajdasági magyar interjúpartnerünktől is hallhattunk ironikus hangú történeteket arról, hogy a magyarországiak szemében milyen irigyelt érték volt a farmernadrág vagy az Adidas-cipő, amelyet a vajdasági magyarok hordtak.

16 A turbofolk szerb népzenei alapokon álló populáris zenei műfaj, amely az 1990-es évek Szerbiájából indult s vált népszerűvé a balkáni országokban.

17 A VMDK Szegedi Tagozatának jelenlegi elnöke egy beszélgetésünk során azt mondta, ma sem táncolnak a bálokon kólót, hiszen mégiscsak „miattuk kellett eljönnünk”. Egy budapesti beszélgetőpartnerünk szavai pedig arra hívták fel a figyelmet, hogy a nosztalgikus emlékezet az elhagyott otthontól távol könnyebben lel táptalajra; amikor otthoni barátainak arról beszélt, nemrég rájött, hogy egy régi jugoszláv dalnak egészen szép mondatai vannak, azok így feleltek: „Mennyire irigylünk! Neked nem volt alkalmad ezeket megutálni.”

\section{Irodalom}

Baker, C. (2006): The politics of performance: transnationalism and its limits in former Yugoslav popular music, 1999-2004. Ethnopolitics, 3., 275-293.

Baker, C. (2007): The concept of turbofolk in Croatia: inclusion/exclusion in the construction of national musical identity. In: Baker, C., Gerry, C. J., Madaj, B., Mellish, L., Nahodilová, J. (eds.): Nation in formation, inclusion and exclusion in Central and Eastern Europe. UCL School of Slavonic and East European Studies Publications, London, 139-158. (Studies in Russia and Eastern Europe; 1.)

Bakić-Hayden, M., Hayden, R. (1992): Orientalist variations on the theme "Balkans": symbolic geography in recent Yugoslav cultural politics. Slavic Review, 1., 1-15.

Baily, J., Collyer, M. (2006): Introduction: music and migration. Journal of Ethnic and Migration Studies, 2., $167-182$.

Bartlett, D. (2000): Fogyasztói kiáltvány a bevásárlóturizmus védelmében. Replika, 39, 125-134.

Berdahl, D. (2010): "(N)Ostalgie” for the present: memory, longing and East German things. In: Buznl, M. (ed.): On the special life of postsocialism. Memory, consumption, Germany. Indiana University Press, Bloomington, 48-59.

Boym, S. (2001): Introduction: taboo on nostalgia? In: The future of nostalgia. Basic Books, New York, xiii-xix.

Boym, S. (2007): Nostalgia and its discontents. The Hedgehog Review, Summer, 7-18.

Burić, F. (2010): Dwelling on the ruins of socialist Yugoslavia: being Bosnian by remembering Tito. In: Todorova, M., Gille, Zs. (eds.): Post-communist nostalgia. Berghahn Books, New York, Oxford, 227-243.

Cohen, S. (1995): Sounding out the city: music and the sensuous production of place. Transactions of the Institute of British Geographers, 4., 434-446. 
Debeljak, A. (1998): Bálványok alkonya. In: Otthon és külföld. JAK - Jelenkor, Budapest, Pécs, 5-37. (Műfordító Füzetek; 15.)

Kovács N. (2009): Szállitható örökség. Magyar identitásteremtés Argentínában (1999-2001). MTA Kisebbségkutató Intézet, Gondolat, Budapest

Leonard, M. (2005): Performing identities: music and dance in the Irish communities of Coventry and Liverpool. Social \& Cultural Geography, 4., 515-529.

Lindstrom, N. (2006): Yugonostalgia: restorative and reflective nostalgia in former Yugoslavia. East Central Europe/ECE, 1-2., 231-242.

Margolies, D. S. (2009): Latino migrant music and identity in the borderlands of the New South. The Journal of American Culture, 2., 114-125.

Martiniello, M., Lafleur, J-M. (2008): Ethnic minorities' cultural and artistic practices as forms of political expression: a review of the literature and a theoretical discussion on music. Journal of Ethnic and Migration Studies. 8., 1191-1215.

Pauker, I. (2006): Reconciliation and popular culture: a promising development in former Yugoslavia? Local-Global Journal, 2., 72-81.

Petrović, T. (2010): Nostalgia for the JNA? Remembering the army in the former Yugoslavia. In: Todorova, M., Gille, Zs. (eds.): Post-communist nostalgia. Berghahn Books, New York, Oxford, 61-81.

Schwandner-Sievers, S. (2010): Invisible - inaudible: Albanian memories of socialism after the war in Kosovo. In: Todorova, M., Gille, Zs. (eds.): Post-communist nostalgia. Berghahn Books, New York, Oxford, 96-112.

Shabtay, M. (2003): 'RaGap': Music and identity among Ethiopians in Israel. Critical Arts Journal, 1-2., 93-105.

Simonett, H. (2007): Banda, a new sound from the barrios of Los Angeles. Transmigration and transcultural production. In: Biddle, I., Knights, V. (eds.): Music, national identity and the politics of location. Ahsgate, Aldershot, 81-92.

Szabó Á. (2006): A nyugat-balkáni kreatív munkaerő migrációja Budapestre. Szakdolgozat. Eötvös Loránd Tudományegyetem Társadalomtudományi Kar.

Todorova, M. (2010): Introduction. From utopia to propaganda and back. In: Todorova, M., Gille, Zs. (eds.): Post-communist nostalgia. Berghahn Books, New York, Oxford, 1-13.

Ugrešić, D. (1996): The confiscation of memory. New Left Review, 8., 26-39.

Ugrešić, D. (2005): Jugó-enciklopédia. Lettre, 58., 13-18.

Valentine, G. (1995): Creating transgressive space: the music of kd lang. Transactions of the Institute of British Geographers, 4., 474-485.

Volčič, Z. (2007): Yugo-nostalgia: cultural memory and media in the former Yugoslavia. Critical Studies in Media Communication, 1., 21-38.

Volčič, Z. (2011): Post-socialist recollections: identity and memory in former Yugoslavia. In: Isar, Y. R., Anheier, H. K. (eds.): Cultures and globalization: heritage, memory and identity. SAGE, London, 187-198. 